\title{
Challenges to Learners with Disabilities in the Higher Education Institutions in
}

\section{Pakistan: A Review}

\author{
* Sajjad Hussain, Lecturer \\ ** Dr. Uzma Shahzadi, Assistant Professor \\ *** Itbar Khan (Corresponding Author)
}

\begin{abstract}
Due to numerous reasons, educating learners with disabilities is an uphill task in Pakistan. Low enrolment and high dropout ratio of such learners need the attention of all stakeholders. The study inquired into the problems faced by learners with disabilities in Universities of Pakistan. The study, by reviewing the literature, examines the accessibility of learners with disabilities in universities, teachers' training, teaching methods, attitudinal challenges, and support services. The study concludes that these students face attitudinal problems both from fellow students and teachers; lack of access to classrooms, libraries, administrative offices; unfriendly teaching methods; untrained teaching staff; hostile environment; lack of assistive devices and transport to, from and inside the campus. The study recommends accessible buildings, accessible transport, capacity development of faculty in special and inclusive education, access to library and administration, curriculum revision, and implementation of policies regarding the inclusive education system.

Keywords: Pakistan, Learners with Disability, Inclusion, Barriers Introduction

The word 'disability' lacks an agreed-upon definition and therefore, it has been defined differently throughout the world. International Classification of Functioning, Disability, and Health (ICF) defines disability as "a complex phenomenon, reflecting the interaction between features of a person's body and features of the society in which he or she lives" (WHO, 2002:2). While Ahmed and Khan (2011) define disability as physical and mental deformity having different types: crippled, deaf, dumb, and mentally retarded. Similarly, Pakistan's National Policy on the Issue of Disability 2002, defines disabled as an individual unfit to get a profitable job or profession because of inability caused by injury, inborn deformity or disease; and include the mentally or physically retarded, and people with visual or hearing impairments (Ahmed, Khan \& Nasem, 2011). Persons with disabilities (PWDs) can be found throughout the world, belonging to different socio-economic backgrounds (Boorse, 2010; Farooq, 2012). Approximately one billion persons - 15 percent of the population of the world- are having various forms of disabilities (Ahmed, Khan \& Naseem, 2011). In the Western Pacific Region, moderate and severe disability is reported to be $16 \%$ (WHO, 2011). Due to this increase in the number of disabling, civilized society has tried her best to restore this weaker section of society (United Nations, 2008). In this connection, the United Nations has also played a vital part in the preservation of the rights of PWDs (Albert, 2004; United Nations, 2005). In the 1970s, the acceptance of human rights for children with disability, the embracing of the declaration of the rights of Mentally Retarded Persons (1971) and the Announcement on the Rights of Disabled Persons (1975) led the General Assembly to integrate children with disabilities (CWDs) by providing them the same rights and access to resources (United Nations,2011). Likewise, celebrating the year of Disabled Person 1981 under the canopy of United Nations, the declaration of $3^{\text {rd }}$ December as the "International Day of Disabled Persons" created awareness regarding the problems faced by CWDs, and measures were taken to address those problems (United Nations, 2005; Jamil, 2017).
\end{abstract}

\footnotetext{
* Department of Social Work, University of Malakand Email: sajjad.hussain@ uom.edu.pk

** Department of Education, University of Sargodha Email: uzmashah_bzu@yahoo.com

*** Faculty of Education, University of Malakand Email: educationmkd@gmail.com
} 
In developing countries including Pakistan, students with disabilities are facing varied problems (Hickman, 2000). Although the government has launched various programs for the welfare of students with disabilities (SWD), the provision of facilities to this marginalized section of the society is still not a top agenda (National Commission for Child Welfare and Development 2005). Recently, the Right to Free and Compulsory Education Bill 2012, has been introduced as per Article 25-A of the Constitution of Pakistan 1973. Still, the Act does not contain any particular provision to SWDs (Singal, 2015). SWDs are those sections of society that are facing societal discrimination, shame, stigma, and have low access to quality education (The Economist Intelligence Unit Limited, 2014).

This study examines the assistance afforded to the learners with infirmities in higher education institutions (HEIs) of Khyber Pakhtunkhwa (KP) Pakistan. The study adds to the current bulk of knowledge on infirmity and helps understand the difficulties faced by learners with disabilities in universities of Khyber Pakhtunkhwa Pakistan.

The study is beneficial for nationwide planning, as well as authorities who are supposed to work with learners with infirmities.

\section{Objectives of the Study}

The current study investigated the hurdles confronted by disabled learners at Pakistani universities. The research also evaluated the attempts at the government level to establish equal opportunity education at HEIs of Pakistan.

\section{Methods and Procedures}

The researchers evaluated the problems and challenges confronted by learners with disabilities in the HEIs of Pakistan. The study is a systematic review of available literature that focused on problems that students are faced with because of their disabilities and spotlighted on accessibility in universities, teaching methods, support services, and transportation.

\section{Significance of the Study}

The study is important for social scientists, academicians, policymakers, scholars, and students because every year students with disabilities get admissions in higher education institutions to equip themselves with modern education so that they can also take part in national development just likable bodied persons. Unfortunately, the HEIs lack sufficient infrastructure to cater to the needs of these students with special needs. This study will help in highlighting the problems of those students who are studying in these prestigious institutions. Moreover, this study will also help the policymakers in planning disable friendly policies for this vulnerable section of society

\section{Literature Review}

Education of students with disabilities has become a serious issue in academic circles throughout the world as mentioned in the Sustainable Development Goals (Jahan, 2015). Similarly, the Incheon Declaration noted that education targets should not be achieved until and unless attained by all. Therefore, it is committed that all education policies will focus on the marginalized, especially those with disabilities (UNESCO, World Education Forum 2015).

In the early $18^{\text {th }}$ century, several nations came up with the concept of the inclusive education system to impart education to every child, irrespective of their differences (Bano, Akhter, Anjum, 2013). Research studies stressed the need for inclusive education instead of distinct education for treating the learners with infirmities on equality basis in terms of facilities and opportunities (Schmidt \& Cagran, 2008). According to Hall, Healey \& Harrison (2002) students with disabilities are marginalized sections of society and they face multiple problems like exclusion, isolation, and discrimination in society. Their disabilities are the major hurdles in their learning and development and do not allow them to integrate into mainstream society (Konur, 2000; Szymanski \& Bilius, 2011).

It is acknowledged that people with disabilities justify special support in learning, both at policy and practical levels (Tinklin, Riddell \&Wilson, 2004). The provision of equal opportunities to learners with disabilities has remained a distant dream in Pakistan (Vickerman \& Blundell, 2010). Students with disabilities face extreme challenges to fulfill their educational needs (Holloway, 2001). The educational institutions need effective and appropriate measures in the form of provision of resources and capacity building to cope with the education of the disabled population, rather than sympathies extended to them (Shah, 2007). 
Pakistan has ratified the 'Convention on the Rights of Persons with Disabilities' to ascertain the rights of persons with disabilities including the right to education. In this connection, Pakistan has also ratified the 'World Conference of Education for All' (UNESCO, 1990), the 'Salamanca Declaration' (UNESCO, 1994), and the 'Dakar Framework for Action of Education for All' (UNICEF, 2004). Pakistan embraced the principle of accessibility in the 'Special Citizens Act 2008' (Special Citizens Act, 2008) 'Special Citizen Bill 2015' (currently pending), that aspires to assure the accessibility of the public places and transportation friendly to the special persons. According to the Act, all public transport should have seats specified for the disabled, and all buildings - public and private - should be easily accessible to them. The progress on the Act, towards the facilitation of PWDs, is very little and insignificant in both private and public sectors (Ahmed \& Khan, 2011; Lewis, 2004).

\section{Disability and University Education in Pakistan}

Tertiary education is imperative for job creation, political empowerment, and nationwide growth (Jameel, 2011). It is producing talented manpower for national development. Moreover, it provides marginalized communities with opportunities by equipping them with access to quality education (Azad, 2008). The policies at the higher education level are aimed to be focused on protecting the rights of special persons (Hardman, \&Dawson, 2008).

Although Pakistan has introduced various programs for achieving the target of 'Education for All', the goal will remain elusive without including students with disabilities. As part of governmental efforts, HEIs of Pakistan have embraced various measures for educating people about disabilities. For instance, universities, "Karachi University, Allama Iqbal Open University", offer degrees and certificates in special education (Akram \& Bashir, 2014).

It has been documented by The Economist Intelligence Unit Limited that only0.01 percent of the visually impaired persons get through primary and secondary education, while just one-third of them eventually reach a higher education institute. Moreover, very few students at Karachi University, Government College University in Lahore, and Quaid- Azam University in Islamabad pass their graduation exams, because of no access to assistive devices and the unavailability of ramps. While the International Islamic University has fitted ramps to help their students reach classrooms in the wheelchair (The Economist Intelligence Unit Limited, 2014).According to Idrees and Ilyas (2012), due to defective policies; learners with disabilities are still faced with problems. Society has to offer equal opportunities for learning in an inclusive environment (Naz \& Aurangzeb, 2002). Keeping the special needs of these students in view, it has been planned by the government of Pakistan that buildings will be designed on the specifications provided by the Ministry of Social Welfare and Special Education Pakistan to give relaxed admittance to recreation centers, ramps, lifts, and toilets (Ahmed, \& Yousaf, 2011). Vickerman \& Blundell (2010) argue that students with disabilities require equal opportunities for expressing themselves through education. Besides, Ruijs, Veen, \& Peetsma (2010) state that if amenities and help are provided at universities, learners with disabilities will acquire all the necessary skills and education to lead a successful life.

In Pakistan, polices have been framed for the introduction of all-encompassing education for learners with disabilities. National Education Policies 1998 and 'National Policy for Persons with Disabilities 2000' are remarkable examples of the provision of education to students with disabilities. Besides, the HEC of Pakistan has framed policies for all-encompassing education at the university level (Hameed, 2008). The basic purpose of these policies is to make sure that learners with special needs are offered a healthy and friendly environment at higher levels of education.

In this connection, the Higher Education Department (HED), Government of Khyber Pakhtunkhwa, has notified facilities for the SWDs and has asked the universities to provide age relaxation of up to 10 years in admission into any degree program in the universities. Furthermore, reservation of at least one seat in MS/MPhil and Ph.D. admissions is also recommended for students with disabilities. Moreover, the provincial government has also issued instructions to the universities to adopt a special package, which includes the waiving off tuition fees and utility bills to students with disabilities. Besides, a special transport facility for movement within the premises of the university is also recommended by the Higher Education Department (Government of Khyber Pakhtunkhwa, 2010). Besides measures at the governmental and institutional level, the teachers at the university level lack in-service training to meet the challenges of wide-ranging education at the university level 
(Mahmoud, Emam, \& Mohamed, 2011). As the problems faced by this special segment of society are of varied nature, therefore, the teacher has to accommodate behavior and show patience to answer their questions and adopt with the pace of the students while delivering lectures (Behlol, 2011). Bartolo held that the realization of inclusive education rests on teachers' preparation as well as the provision of a favorable environment to the students in educational institutions. Such students face an additional burden as they must accept an environment for education which is not appropriate for them (Tinklin \& Hall, 1999; Rieser, 2012). In Pakistan, the HEIs lack adequate infrastructure, trained faculty, clinical services, and proper learning material which add to the problems of these vulnerable students and lead to their exclusion from the mainstream education system (Yasmeen, Minto \& Khan, 2010). Inclusive education demands classroom space, design of classroom according to the needs of the students with multiple disabilities, lighting arrangements, and teaching methods (Safder, Akhtar, Fatima, \& Malik 2012). The teaching methodology is very important in an inclusive environment at higher education institutions (UNESCO, 2009).

In Pakistan, students with disabilities face various problems in higher educational institutions, including inappropriate curriculum, learning difficulties, defective methods, and unavailability of equipment that badly affects their performance in regular and/or inclusion setup (Bano, Akhter, \& Anjum, 2013). Similarly, the students with sight problems face difficulty in reading the whiteboard and cannot take part in discussions in the class. Also, some of the teachers do not allow students to record their lectures on audio recorders which creates problems for the students to follow lectures (Fuller, Healey, Bradley, \& Hall, 2004). Moreover, the attitude of faculty members towards these students is also vital for the success of inclusive education in universities (Rao, 2004). According to Idrees and Ilyas (2012), these students with disabilities face extreme conditions due to the negative attitude of the public and the social stigma attached to disability. Besides, the attitude of teachers and normal classmates is often negative towards students with disabilities at university (Zakarya, 1995; Mittler, 2012). However, the degree of rejection of PWDs depends on the type of disability and gender. According to Groce (2004), it is admitted worldwide that the greatest hurdle to learners with disabilities is the prejudices, stigma, and bias (Despouy, 1991). Inequity, based on gender discrimination, is observed in societies, where boys are given more preference than girls. As a result, investment in education for girls is much less than boys. In addition to these problems, the learners with disabilities face accessibility problems, as well as lack assistive devices. Accessibility to educational institutions is very important for learners with disabilities (Rimmerman \& AratenBergman, 2005). Low enrolment and high dropout rates in HEIs are due to the lack of accessibility to institutions of tertiary education (Johnson, 2006). Without accessible buildings, SWDs cannot achieve the goals of education (UNESCO, 2015). Assistive devices are the basis for the mobility of such students. Services for such students mean those physical and human resource arrangements that lead to the integration and addition of learners with unusual requirements (Groce, 2004). In universities of Khyber Pakhtunkhwa, assistive devices like ramps, lifts, wheelchairs are required for reaching classrooms, library, and administrative offices (Hamad, 2001). These universities lack space for the movement of students with wheelchairs in the university. Furthermore, there are no physiotherapy services, which add to the problems faced by this vulnerable section of society (Idrees \& Ilyas, 2012).

\section{Conclusion}

The study concludes that all the universities of Khyber Pakhtunkhwa lack facilities for students with disabilities which include access to classrooms/laboratories, lack of training to the teaching staff, the environment of education institutions, teaching methodologies, and negative attitudes. As part of the government policy, the Higher Education Commission of Pakistan has asked all the universities to give the required facilities to such students. Despite these efforts on the part of the government, the universities have yet to provide infrastructure and facilities like ramps, adjustable chairs, hearing aids, academic concession, lifts for reaching multi-story buildings, hostel facility on the ground floor, fees concession, special seats (quota) in MS/MPhil/Ph.D. admission, and provision of assistive devices. Even though policies have been framed from time to time to facilitate students with disabilities in universities of Pakistan, very little progress has been made in universities of KP because there is a lack of will, interest, and lack of coordination between implementing bodies. Moreover, there is the dearth of research into the needs of the special persons and practical solutions, both on the part of the 
students as well as the faculty. There is a want of management between the HEC and Universities of Khyber Pakhtunkhwa for the provision of maximum facilities to pupils with infirmities.

\section{Recommendations}

The research urges that the framed policies to enable disabled students are not shallow rhetoric but are really meant and fully implemented. The teaching methods should be modified to the special needs of the disabled population and the curriculum should be revised in conformity with the requirements of the pupils with incapacities. The learning and research institutes should modify the existing buildings to make them disabled-friendly and new buildings designed in a way that they are more accessible to special persons. The role of HEC is vital to facilitate disabled students at universities.

The HEC of Pakistan and the Universities of KP should work with the Department of Social Welfare to identify gaps in the existing policies. The HEC should organize training for the newly appointed teachers at the universities regarding special education to students with disabilities. Besides, refresher courses should be organized for already trained teachers. The universities should give pick and drop facilities to the day scholars while hostel facility should be provided to such dependent students at accessible places.

The transport facility should contain a lift system for boarding the bus. The universities should provide free assistive devices to these vulnerable students to ensure their education at the university level. Libraries and recreation centers should also be made accessible while recreation centers should also be designed disabled-friendly.

The universities of KP should also establish Disability Centers where counseling services can be provided to students with disabilities. Moreover, the universities should organize workshops and seminars regarding anxiety and stress management for these vulnerable students.

Civil society organizations can also play an effective role through advocacy and awareness for the delivery of equal opportunities of education to students with infirmities. A comprehensive education system should be introduced in all universities of Pakistan for integrating them and for providing equal opportunities to all students.

To solve the problems of SWDs on a sustainable basis, the HEC should ensure that while planning for the development of universities, the needs of such students should be given top priority.

\section{References}

Ahmed, M and Khan, A. (2011). The policies of the United Nations and their implementation: A comparative study of policy implementation in Pakistan. Journal of Political Studies, 18, (1), 125-140.

Ahmed, S., \& Yousaf, M. (2011). Special education in Pakistan: In the perspectives of educational policies and plans. Academic Research International, 1, (2), 228-31.

Ahmed, M., Khan, A., \& Nasem, F., (2011). Policies for special persons in Pakistan Analysis of policy implementation. Berkeley Journal of Social Sciences, 1, (2), 1-11.

Akram, B. \& Bashir, R. (2014). Special education deaf children in Pakistan: An overview. Journal of Elementary Education, 22, (2), 33-44.

Albert, B. (2004). Disability KaR briefing note: The social model of disability, human rights, and development. Retrieved on January 13, 2017 from: http://enil.eu/wp-content/uploads/2012/07/ The-social-model-of-disability-human-rights-development_2004.pdf

Azad, J. L. (2008). Financing and management of higher education in India: The role of the private sector. Gyan Publishing House.

Bano, H., Akhter, N \& Anjum, N. (2013). Analysis of educational facilities and opportunities for students with special needs at the University of the Punjab. Journal of Education and Research, 16, (1), 1-14.

Bartolo, P. A. (2010). The process of teacher education for inclusion: The Maltese experience. Journal of Research in Special Educational Needs, 10(1), 139-148.

Boorse, C., (2010). "Disability and medical theory," in Philosophical reflections on disability, D. C. Ralston, \& J. Ho (eds.), Dordrecht: Springer, 55-90.

Bahlol, M. (2011). Inclusive education: Preparation of teachers, challenges in the classroom, and prospects.

Despouy L. (1991). Human rights and disability. United Nations Economic and Social Council, Doc. E/CCN.4/Sub.2/1991/31. NY: United Nations. 
Farooq, M.S. (2012). Problems faced by students with special needs in ordinary Pakistani schools. Journal of Quality and Technology Management, VIII, (I), 13 - 27.

Government of Pakistan. (2019). A roadmap for stability, growth, and productive employment. Government of Pakistan Finance Division Islamabad

Government of Pakistan. (2019). Pakistan Economic Survey 2018-19. Finance Division Government of Pakistan. Retrieved on October 7, 2019 from: http://finance.gov.pk/survey/chapters_19/ Economic_Survey_2018_19.pdf

Farooq, M.S. (2012). Problems faced by students with special needs in ordinary Pakistani schools. Journal of Quality and Technology Management, VIII, (I), 13 - 27.

Fuller, M., Healey, M., Bradley, A., \& Hall, T. (2004). Barriers to learning: A systematic study of the experience of disabled students in one university. Studies in higher education, 29(3), 303-318.

Government of Khyber Pakhtunkhwa. (2010). Adoption of special package for physically handicapped students. Government of Khyber Pakhtunkhwa, Higher Education, Archives \& Library Department.

Groce, N. E. (2004). Adolescents and youth with disabilities: Issues and challenges. Asia Pacific Disability Rehabilitation Journal, 15(2), 13-32.

Hall, T., Healey, M., \& Harrison, M. (2002). Fieldwork and disabled students: Discourses of exclusion and inclusion. Transactions of the Institute of British Geographers, 27(2), 213-231.

Hamad, A. (2001). The counseling needs for physical handicap and their relation to some variables in the Israbeel district. Unpublished thesis. Anouk University, Aman; Jordan.

Hameed, A. (2008). UN Convention on the Rights and Dignity of Persons with Disability: A call for action on poverty, discrimination, and lack of access. Creating access for people with disabilities to higher education in Pakistan. Lahore. Retrieved on January 22, 2017 from: from www.lcint.org/download.php?id=498

Hardman, M. L., \& Dawson, S. (2008). The impact of federal public policy on curriculum and instruction for students with disabilities in the general classroom. Preventing School Failure: Alternative Education for Children and Youth, 52(2), 5-11.

Hickman, L. (2000). Living in my skin: The insider's view of life with a special needs' child. San Antonio, TX: Communication Skill Builders.

Holloway, S. (2001). The experience of higher education from the perspective of disabled students. Disability and Society, 16(4), 597-615.

Idrees, B., \& Ilyas, R. (2012). Discrimination and stigmatization of physically disabled students in a general education environment in Pakistan: A case study. Academic Research International, 2(2), 622-26.

Jameel, S. S. (2011). Disability in the context of Higher Education: Issues and concerns in India, Electronic Journal for Inclusive Education, 2 (7), 1-21.

Jamil, K. (2017). World Health Organization Global Disability Action Plan 2014-2021: Challenges and perspectives for physical medicine and rehabilitation in Pakistan. Journal of Rehabilitation Medicine, 49: xx-xx. Doi: 10.2340/16501977-2149.

Jahan, S. (2015). Human Development Report 2015. Work for Human Development. United Nations Development Programmed 1 UN Plaza, New York, NY 10017, USA. Retrieved on February 20, 2016, from: http://hdr.undp.org/sites/default/files/2015_human_development_report.pdf

Johnson, A. L. (2006). Students with disabilities in post-secondary education: Barriers to success and implication to professionals. Vistas Online. Retrieved on January 14, 2017, from: http://counselingoutfitters.com/vistas2006

Khatoon, A. (2003). A historical and evaluative study of special. Unpublished doctoral thesis: Special Education Department, University of Karachi, Karachi.

Konur, O. (2000). Creating enforceable civil rights for disabled students in higher education: An institutional theory perspective. Disability and Society, 15(7), 1041-1063.

Lewis, A. (2004). 'And when did you last see your father?'Exploring the views of children with learning difficulties/disabilities. British Journal of Special Education, 31(1), 3-9.

Mahmoud, M. Emam, M. M., \& Mohamed, A. H. H., (2011). Preschool and primary school teachers' attitudes towards inclusive education in Egypt: The role of experience and self-efficacy. Procedia - Social and Behavioral Sciences, 29, 976 - 985. 
Mittler, P. (2012). It is our Convention: Use it or lose it? Disability, CBR \& Inclusive Development, 23, (2), 7-21.

National Commission for Child Welfare and Development. (2005). National Plan of Action for Children, Pakistan. Ministry of Social Welfare and Special Education, Islamabad Pakistan Islamabad. Retrieved on February 20, 2016, from: http://hivhealthclearinghouse.unesco.org/ sites/default/files/resources/iiep_npa_pakistan.pdf

Naz, S., \& Aurangzaib, S. (2002). A study of Islamic concepts about disables. Un-Master's Thesis University of the Punjab. Unpublished.

Rao, S. (2004). Faculty attitudes and students with disabilities in higher education: A literature review. College Student Journal, 38(2), 191-198.

Rieser, R. (2012). Implementing inclusive education: A Commonwealth guide to implementing Article 24 of the UN Convention on the Rights of Persons with Disabilities. Commonwealth Secretariat.

Rimmerman, A., \& Araten-Bergman, T. (2005). Legislation of handicapped rights and its implementation in Israel: Trends and future directions. Social Security Journal, 69, 11-31.

Ruijs, N. M., Veen, I. V., \& Peetsma, T. T. (2010). Inclusive education and students without special educational needs. Educational Research, 52(4), 351-390.

Safder, M., Akhtar, M., Fatima, G., Malik, M. (2012). Problems faced by students with hearing impairment in inclusive education at the university level. Journal of Research and Reflections in Education. Vol.6, (2), 129 -136

Schmidt, M. \&Cagran, B. (2008). Self-concept of students in inclusive settings. International Journal of Special Education, 23 (1), 8-17.

Shah, S. (2007). Special or mainstream? The views of disabled students. Research Papers in Education, 22(4), 425-442.

Shakespeare, T., \& Watson, N. (2001). The social model of disability: An outdated ideology? In exploring theories and expanding methodologies: Where we are and where we need to go :( 9-28). Emerald Group Publishing Limited.

Singal, N. (2015). Education of children with disabilities in India and Pakistan: An analysis of developments since 2000. Retrieved on January 13, 2017, from: http://unesdoc.unesco.org/ images/0023/002324/232424e.pdf

Special Citizens Act, (2008). Government of Pakistan.

Szymanski, C. F., \& Bilius, M. (2011). A case study in the globalization of disability rights: The compatibility of Lithuania's process for determining the legal incapacity of disabled persons with international legal standards. Baltic Journal of Law Politics, 4(1), 83-105.

The Economist Intelligence Unit Limited (2014). Moving from the margins: Mainstreaming persons with disabilities in Pakistan. London: British Council

Tinklin T., Riddell, S., \& Wilson, A. (2004). Policy and provision for disabled students in higher education in Scotland and England: The current state of policy. Studies in Higher Education, 29(5), 637-657.

Tinklin, T., \& Hall, J. (1999). Getting around obstacles: Disabled student's experiences in higher education in Scotland. Studies in Higher Education, 24, (2), 183-194.

UNESCO, World Education Forum. (2015). Education 2030 Incheon Declaration and Framework for Action: Towards inclusive and equitable quality education and lifelong learning for all. Incheon: World Education Forum. Retrieved on January 25, 2017 from: http://en.unesco.org/ world-education-forum-2015/incheon-declaration

UNESCO. (1990). the world conference on education for all. Retrieved on July 2, 2016 from http://www.unesco.org/education/efa/ed_for_all/background/world_conference.

UNESCO. (2015). The right to education for persons with disabilities: Overview of the measures supporting the right to education for persons with disabilities reported on by Member States. Retrieved on February 07, 2017 from:http://unesdoc.unesco.org/images/0023/002325/ 232592E.pdf

UNESCO. (1994). The Salamanca statement and framework for action on special needs education. Paper presented at the World Conference on Special Needs Education: Access and Quality, Salamanca, Spain. 
UNICEF. (2004). The Dakar framework for action. Education for all. Retrieved on January 10, 2016, from http://www.unicef.org/ sowc04/Sewco4_education_for_all.html.

UNICEF. (2007). Promoting the rights of children with disabilities. Innocent Digest, 13, 1-68.

UNICEF. (2013). the state of the world's children: Children with disabilities. UN. Retrieved on January 13, 2017 from: https://www.unicef.org/pacificislands/UNI137485 (1).pdf

United Nations (November 2005). UNews Monthly Newsletter of the UN Information Centre, New Delhi http://www.unic.org.in/items/Newsletter_Nov2005.pdf

United Nations, (2011). Basic facts about the United Nations. United Nations Department of Public Information New York. Retrieved on November 25, 2016 from: http://munkiconference. weebly.com/uploads/1/5/4/2/15422056/basic-facts-about-the-un.pdf

United Nations. (2008). Convention on the rights of children with disabilities, Advocacy Toolkit Professional Training Series No. 15. Retrieved on December 25, 2016, from: http://www.ohchr.org/Documents/Publications/AdvocacyTool_en.pdf.

UNESCO. (2009). Policy guidelines on inclusion in education. Retrieved on February 6, 2017, from: http://unesdoc.unesco.org/images/0017/001778/177849e.pdf

Vickerman, P. \& Blundell, M. (2010). Hearing the voices of disabled students in higher education. Disability and Society, 25(1), 21-32.

World Health Organization. (2011). Disability and rehabilitation: World report on disability, 2011.http://www.who.int/disabilities/world_report/2011/report/en/

World Health Organization. (2002). Towards a common language for functioning, disability, and health: The international classification of functioning, disability, and health, (p.2) Retrieved on 23 January 2017, from http://www.who.int/classifications/icf/training/icfbeginners guide.pdf

Yasmeen, S., Minto, H., \& Khan, N. (2010). Policy and practice in the educational inclusion of children and young people with visual impairment in Sri Lanka and Pakistan. The Educator, $22(2), 17-22$.

Zakarya. (1995). Zero rejected schools. New Education Journal, 1, 65-87 